\title{
Studies on Ricinus Lipase Enzyme Isolated from Castor Seeds
}

\author{
ALKA SRIVASTAVA ${ }^{*}$, RASHMI MOHAN MATHUR ${ }^{1}$, \\ RACHNA PRAKASH ${ }^{1}$ and SHASHI AGRAWAL' ${ }^{1}$ \\ ${ }^{* 1}$ Department of Chemistry D.G. (PG) College, Kanpur, India. \\ ${ }^{2}$ Department of Chemistry D.B.S College, Kanpur, India.
}

http://dx.doi.org/10.13005/ojc/320250

(Received: January 19, 2016; Accepted: February 12, 2016)

\begin{abstract}
Healthy and bold seeds of castor variety "Aruna" were collected. The de-hulled castor kernels were separated from seed coat and finely grounded in an electric grinder. The powdered kernels were passed through 60 mesh sieve and defatted using n-hexane in a soxhlet extractor. After complete extraction of oil seed meal was made free from solvent at low temperature. The defatted seed meal was pulverized and again passed through 60-mesh sieve to get final product .The RICINUS LIPASE source thus, obtained was stored in a screw capped glass vial and kept in a desiccator. As and when required portions from this preparation were used in further enzymatic studies.
\end{abstract}

Keywords: Ricinus Lipase, Germinated castor seeds, Cotyledons.

\section{INTRODUCTION}

In plant seeds particularly in castor seeds the utilization of the storage fats is initiated by the stepwise hydrolysis of the tri-glycerides to di and mono glycerides and ultimately to free fatty acids and glycerol ${ }^{1}$. These are converted to sucrose by a long glyconeogenic pathway ${ }^{2,3}$ These reactions are commonly catalyzed by the enzyme lipase. In almost all oil seeds lipase enzyme catalysed hydrolysis of triglycerides take place during germination as enzyme lipase is activated mainly in the seedling tissues of different plant species ${ }^{4,5,6}$. The castor bean has also been reported to possess powerful lipase activity which is responsible for the hydrolysis of triglycerides. The lipase present in castor bean has a unique behaviour and possess some extraordinary characteristics, in contrast to the other oilseeds in which lipase is activated only during germination, In castor bean lipase is activated during germination in dormant seeds and germinated seeds both ${ }^{7}$.

It has been observed that castor bean contains two lipases .one enzyme is associated with the membranes of spherosomes (lipid bodies) and is active in dormant or resting seeds, This lipase 
is active only in acid $\mathrm{pH}$, hence is termed as acid lipase and is capable of hydrolyzing triglycerites with maximum activity at $\mathrm{pH}$ 4.2-5.0 The activity of the $\mathrm{pH}$ decreases sharply during germination ${ }^{8,9,10}$.

The other enzyme, alkaline lipase is associated with membrane of glyoxysomes and endoplasmic reticulum. It is active in alkaline $\mathrm{pH}$ with optimum activity at $\mathrm{pH} 9$ and is capable of acting only on mono glycerides. This enzyme is inactive in dormant seeds.

\section{MATERIALS AND METHODS}

\section{Preparation of Ricinus Lipase source from dormant castor seed}

Healthy and bold seeds of castor variety 'Aruna' were collected. The dehulled castor kernels were seperated from seed coat and finally grounded in an electric grinder. The powdered kernels were passed through 60 mesh sieve and defatted using n-hexane in a soxhlet extractor. After complete extraction of oil seed meal was made free from solvent at low temperature. The defatted seed meal was pulverized and again passed through 60-mesh sieve to get final product. The RICINUS LIPASE source thus obtained was stored in a screw capped glass vial and kept in a desiccator. As and when required portions from this preparation were used in further enzymatic studies.

\section{Preparation of Ricinus Lipase Source from germinated castor seeds}

Healthy and bold seeds of castor variety of "Aruna" were soaked in a distilled water for twenty four hours. Water was drained off and water soaked seeds were placed on germinating papers in a petri dish and were allowed to germinate for 5 days. Seed coats of five day old germinated castor seeds were carefully removed and cotyledons along with sprouts were subsequently crushed to fine thick paste in a pestle and mortar. Freshly prepared fine thick paste was always used as RICINIUS LIPASE source in subsequent experiments.

Measurement of Rates of Hydrolysis and Lipase Activity using Ricinus Lipase Source from Dormant and Germinating Castor Seeds

\section{Standard Procedure}

Unless otherwise specified a simplified, standard procedure as adopted by Longencker and Haley was employed with some modifications for the measurement of rates of hydrolysis of various glycerides and lipase activity using Ricinus Lipase source from both, dormant and germinated castor seeds. A fixed weight of substrate (vegetable oils) $(1.0 \mathrm{~g})$ was placed in a hard glass screw capped vial and two drops of toluene was added to it. The mixture was thoroughly mixed followed by the addition of fixed weight of Ricinus Lipase source $(0.1 \mathrm{~g})$ enzyme material in case of dormant seeds and $1.6 \mathrm{~g}$ (on fresh weight basis) in case of enzyme material from 5 day old germinated castor seeds). 1.6g Fresh-weight of lipase source -from germinated castor seeds -was equal to $1 \mathrm{~g}$ of lipase source from dormant seeds on dry weight basis. distilled water $(2.0 \mathrm{ml})$ was then added to the exaction mixture followed by short stirring for uniform mixing of the contents of the vial. $\mathrm{pH}$ of the reaction mixture was set to 4.8 by the addition of $1 \mathrm{~N}$ acetic acid solution $(.7 \mathrm{ml})$. The contents of the viral were again stirred and incubated at $35^{\circ} \mathrm{C}$ for a constant period of time (30 min.). After the completion of the incubation period, the reaction mixture was transferred to a conical flask containing $40 \mathrm{ml}$ of $95 \%$ hot ethanol to stop the reaction. The remains in the vial were rinsed twice with hot alcohol in such a way that the total volume of the alcohol added comes to $50 \mathrm{ml}$ contents of the flask containing fatty acids released from glycerides were titrated with IN sodium hydroxide solution using phenolphthalein as an indicator. A blank experiment without enzyme source was also conducted along with each set of experiment with different substrate.

In the case of experiments containing Ricinus lipase source from germinated seeds an additional blank experiment without substrate was also conducted to determine fatty acids released from endogenous castor oil present in Ricinus Lipase source from germinated seed, so that fatty acid released from the substrate added in the reaction mixture could be calculated accurately. The $\%$ lipolysis / hydrolysis of the substrate (glycerides) in each experiment was calculated by the expression.

$\%$ lipolysis $/$ hydrolysis $=($ vol. of $1 \mathrm{~N}$ alkali (sample $))-$ (vol.of $1 \mathrm{~N}$ alkali (blank))* 100 Saponification no. of a substrate- Acid value of substrate 


\begin{abstract}
Lipase Activity
Measurement of lipase activity of lipase source from dormant acid germinated castor seeds was determined using standard procedure which indicate micro-molar concentration of free fatty acids released from substrate per minute from $10 \mu \mathrm{g}$ lipase source and is expressed in m mole fatty acid released per minute $10 \mathrm{mg}$ enzyme per source.
\end{abstract}

Factor Affecting Ricinus Lipase Catalysed) Hydrolysis of Vegetable Oils used as Substrate

\section{Effect of $\mathrm{pH}$}

In both the sets of experiment using Ricinus Lipase source from dormant and germinated seeds the reaction condition of enzyme catalysed hydrolysis of various substrate (vegetable oil) were maintained as per standard procedure and $\mathrm{pH}$ of reaction mixture was varied maintaining $\mathrm{pH}$ at 4.0 , 4.8, 5.0 and 5.5 in different experiments by the addition of $1 \mathrm{~N}$ acetic acid solution results on the effect of $\mathrm{pH}$ on \% lipolysis of glycerides and Ricinus lipase activity were calculated as given in standard procedure

\section{Effect of temperature}

In both types of experiment with dormant and germinated seeds as lipase source, the effect of temperature on Ricinus Lipase catalyzed hydrolysis of vegetable oils was determined using the standard procedure with the exception that the incubation temperature of the reaction was maintained at 30,35 , 40,45 and 50 deg celcius in different experiment.

\section{Effect of reaction time}

In order to determine the effect of reaction period on enzyme catalyzed lipolysis of various substrate (vegetable oils) the reaction were conducted at five variable time viz. $15,30,60,90$ and $120 \mathrm{mi}$ Other condition were maintained same as reported in standard procedure

\section{Effect of enzyme Concentration}

In both the sets of experiment using lipase source from dormant and germinated castor seeds. effect of enzyme concentration on the rates of hydrolysis of various vegetable oil was determined using four variables of enzyme concentration. In the case of experiments using iipase .source from dormant seeds the concentration of enzyme source was maintained at $.05,0.1,0.15$ and $0.20 \mathrm{~g}$ in the whole experiment was maintained at 1.6, 2.1 ,2.6 and $3.1 \mathrm{~g}$ on fresh weight basis. Rest of reaction condition were same as per in the standard condition

\section{Effect of Substrate concentration}

In both sets of experiments employing source from dormant and germinating castor seeds vegetable oils namely castor oil, linseed oil cottonseed oil, olive oil and coconut oil were used as substrate, The concentration of each substrate was maintained at four variables viz. .5, 1.0, 1.5 and $2.0 \mathrm{~g}$. The concentration of enzyme ad other components of reaction mixture were same as used in the standard procedure

\section{Effect of Inorganic salts}

Effect of series of inorganic salts on the rate of enzyme catalysed lipolysis/hydrolysis of various substrate was determined employing lipase source from dormant seeds only. In each experiment $0.1 \mathrm{~g}$ of inorganic salt was added additionally to the digestion mixture before the addition of $0.1 \mathrm{~N}$ acetic acid solution. The concentration of substrate enzyme and other reaction conditions were same as per in the standard procedure. Various inorganic salts used were lead acetate lead chloride, cobalt acetate chromium acetate, chromium chloride, calcium chloride and cobalt chloride

\section{RESULTS AND DISCUSSION}

\section{Ricinus lipase : Measurment of rate of hydrolysis an]) lipase activity}

In plant seeds, particularly iii oleaginous seeds, breakdown and utilization of reserve oil/fat begins with stepwise hydrolysis of triglycerides to di- and mono-glycerides and then to glycerol and fatty acid-, which are then used in the biosynthesis of sucrose through glyconeogenic pathway. The steps involved in the conversion of triacyiglycerides to free fatty acids and glycerol are catalysed by enzyme lipase (glycerol and hydrolase E.C..3.1.1.3). reports are known indicating the activation of lipase enzymes of plant seeds only during germinated phase as the enzyme lipase is activated mainly in seedling tissues of different plant species Like other oilseeds , castor seeds also possess lipase system but -nature amid characteristics ef Ricinus Lipase or castor bean lipase are different than -those of other oleaginous 
seeds. In contrast to other oil seed, Ricinus Lipase is active in dormant seeds in addition to germinated seeds. The reason for the activation Ricinus Lipase in both, dormant and germinated stages has been attributed to the presence of two different lipases in castor bean of which one is activated during dormant seeds (at acidic $\mathrm{pH}$ ). The acid lipase is capable of hydrolysing tri, di- and monoglycerides to fatty acids and glycerol. The enzyme is highly active during germination. However, the reason of activation of this lipase in dormant seeds and decrease in its activity during germinated seeds has not yet been

Table 1: Comparative Status of Rates of Hydrolysis of Different Substrate Catalysed

By Ricinus Lipase Source From Dormant and Germinated Castor Seeds Under Standard Conditions

\begin{tabular}{lcc}
\hline Substrate & \multicolumn{2}{c}{ Rates of hydrolysis } \\
Ricinus & $\begin{array}{c}\text { Lipase Source } \\
\text { Ricinus } \\
\text { from DCS }\end{array}$ & $\begin{array}{c}\text { Lipase Source } \\
\text { from GCS }\end{array}$ \\
\hline Castor oil & 45.00 & 4.00 \\
Linseed oil & 34.02 & 2.16 \\
Cottonseed oil & 31.65 & 1.29 \\
Olive oil & 41.32 & 3.04 \\
Coconut oil & 40.29 & 2.50 \\
\hline
\end{tabular}

*Data given is a mean of triplicate analysis DCS= Dormant Castor Seed; GCS= Germinated castor Seed

Table 3 A: Effect of Ph on The Rates Of Hydrolysis of Different Substrates Catalyzed by Ricinus Lipase Source from Dormant Castor Seeds

\begin{tabular}{lcccc}
\hline \multirow{2}{*}{ Substrate } & \multicolumn{4}{c}{ Rates of Hydrolysis (\%) } \\
& pH4.0 & pH4.8 & pH5.0 & pH5.5 \\
& & & & \\
\hline Castor oil & 10.45 & 45.00 & 10.01 & 8.20 \\
Linseed oil & 8.71 & 34.02 & 8.09 & 8.00 \\
Cottonseed oil & 10.29 & 31.65 & 8.90 & 8.00 \\
Olive oil & 8.09 & 41.32 & 9.01 & 8.90 \\
Coconut oil & 9.00 & 40.29 & 8,40 & 7.32 \\
\hline
\end{tabular}

elucidated. Moreover such a pattern of lipolytic action in dormant seeds has yet not been observed to other oleaginous seeds wherein lipases are activated only in germinated seeds

The alkaline lipase is reported to be inactive during dormant seeds but its activity increases markedly during germination. However, this enzyme is capable of hydrolyzing monoglycerides only. It is not known, how reserve glycerides in castor seeds are converted to monoglycerides during germination as acid lipase present in the seed for purpose becomes inactive during phase.

Table 2: Effect of germination on the Activation of Ricinus Lipase over Various Substrates under Standard Condition

\begin{tabular}{lcc} 
activity* & \multicolumn{2}{c}{$\begin{array}{c}\text { Ricinus lipase } \\
\boldsymbol{\mu} \text { mole F.A. released }\end{array}$} \\
& $\begin{array}{c}\boldsymbol{2} \text { Ricinus } \\
\text { minute 10mg lipase source }\end{array}$ \\
\cline { 2 - 3 } & $\begin{array}{c}\text { Lipase Source } \\
\text { from DCS }\end{array}$ & $\begin{array}{c}\text { Ripase Source } \\
\text { from GCS }\end{array}$ \\
\hline Castor oil & 22.1 & 2.33 \\
Linseed oil & 16.7 & 1.06 \\
Cottonseed oil & 15.5 & 0.62 \\
Olive oil & 20.2 & 1.40 \\
Coconut oil & 19.7 & 1.20 \\
\hline
\end{tabular}

Table 3 B: Effect of pH on the Activity of Ricinus Lipase Source Obtained from Dormant seeds using various substrate

\begin{tabular}{lcccc}
\hline Substrate & \multicolumn{4}{c}{ Ricinus lipase activity* } \\
& \multicolumn{4}{c}{ 10mg lipase source $\left.{ }^{-1}\right)$} \\
& pH4.0 & pH4.8 & pH5.0 & pH5.5 \\
\hline Castor oil & 5.13 & 22.1 & 4.99 & 4.02 \\
Linseed oil & 4.37 & 16.7 & 3.97 & 3.92 \\
Cottonseed oil & 3.03 & 15.5 & 4.35 & 2.91 \\
Olive oil & 3.95 & 20.2 & 4.40 & 4.30 \\
Coconut oil & 4.13 & 19.7 & 4.10 & 3.57 \\
\hline
\end{tabular}


In light of the above information efforts on the measurement of Ricinus acid lipase activity in both dormant and germinated seeds have been made to determine comparative status of acid lipase activity in both the phases in an attempt to contribute to the existing knowledge in the area

Table 4 A: Effect of P11 on the Rates of Hydrolysis of Different Substrates Catalyzed by Ricinus Lipase Source from Germinated Castor Seeds

\begin{tabular}{lllll}
\hline \multirow{2}{*}{ Substrate } & \multicolumn{4}{c}{ Rates of Hydrolysis (\%)* } \\
& pH4.0 & pH4.8 & pH5.0 & pH5.5 \\
\hline Castor oil & 4.00 & 4.00 & 4.00 & 4.00 \\
Linseed oil & 2.14 & 2.16 & 2.10 & 2.12 \\
Cottonseed oil & 1.20 & 1.29 & 1.22 & 1.23 \\
Olive oil & 2.91 & 3.04 & 2.99 & 2.65 \\
Coconut oil & 2.42 & 2.50 & 2.48 & 2.51 \\
\hline
\end{tabular}

In order to achieve this goal two sets of experiments were performed were which involved the use of both dormant and germinated seeds as source of Ricinus lipase to measure its lipolytic activity on various substrate (vegetable oils)

Table 4 B: Effect of pH on the Activity of Ricinus LipaseSource Obtained from Germinated seeds using various Substrates

\begin{tabular}{|c|c|c|c|c|}
\hline \multirow[t]{2}{*}{ Substrate } & \multicolumn{4}{|c|}{$\begin{array}{c}\text { Ricinus lipase activity* } \\
\text { ( } \mu \text { mole F.A. released minute } \\
\text { 10mg lipase source }{ }^{-1} \text { ) }\end{array}$} \\
\hline & pH4.0 & pH4.8 & pH5.0 & pH5.5 \\
\hline Castor oil & 2.33 & 2.33 & 2.33 & 2.33 \\
\hline Linseed oil & 1.04 & 1.02 & 1.03 & 1.03 \\
\hline Cottonseed oil & 0.56 & 0.63 & 0.59 & 0.60 \\
\hline Olive oil & 1.42 & 1.48 & 1.48 & 1.26 \\
\hline Coconut oil & 0.97 & 1.20 & 1.06 & 1.10 \\
\hline
\end{tabular}

Table 5 A: Effect of Temperature on the rates of Hydrolysis of Different Substrates Catalysed by Ricinus Lipase Source from Dormant Seeds

\begin{tabular}{llllll}
\hline \multirow{2}{*}{ Substrate } & \multicolumn{5}{c}{ Rate of Hydrolysis (\%) } \\
& $\mathbf{3 0} \mathbf{C}$ & $\mathbf{3 5}^{\circ} \mathbf{C}$ & $\mathbf{4 0} \mathbf{C}$ & $\mathbf{4 5}^{\circ} \mathbf{C}$ & $\mathbf{5 0} \mathbf{~} \mathbf{C}$ \\
& & & & & \\
\hline Castor oil & 25.21 & 45.00 & 45.29 & 42.33 & 31.00 \\
Linseed oil & 30.02 & 34.02 & 34.99 & 33.25 & 30.69 \\
Cottonseed oil & 29.12 & 31.65 & 39.50 & 35.29 & 28.12 \\
Olive oil & 20.19 & 41.32 & 39.89 & 35.00 & 30.09 \\
Coconut oil & 28.51 & 40.29 & 39.92 & 38.10 & 36.20 \\
\hline
\end{tabular}

Table 5 B: Effect of Temperature on the rates of Hydrolysis of Different Substrates Catalysed by Ricinus Lipase Source from Dormant Seeds

\begin{tabular}{lccccc}
\hline Substrate & \multicolumn{5}{c}{ Ricinus lipase activity ${ }^{*} \boldsymbol{\mu}$ t mole F.A. } \\
& $\begin{array}{l}\text { released minute-1 } \\
\text { 10 } \mathbf{m g} \text { lipase source) }\end{array}$ \\
& $\mathbf{3 0 ^ { \circ } \mathbf { C }}$ & $\mathbf{3 5}^{\circ} \mathbf{C}$ & $\mathbf{4 0} \mathbf{C}^{\circ}$ & $\mathbf{4 5}^{\circ} \mathbf{C}$ & $\mathbf{5 0}^{\circ} \mathbf{C}$ \\
\hline Castor oil & 12.3 & 22.1 & 22.2 & 20.7 & 15.2 \\
Linseed oil & 14.6 & 16.7 & 17.7 & 16.2 & 15.0 \\
Cottonseed oil & 15.0 & 14.2 & 15.5 & 19.3 & 17.2 \\
Olive oil & 13.7 & 9.8 & 20.2 & 19.5 & 17.1 \\
Coconut oil & 14.7 & 13.9 & 19.7 & 19.5 & 18.6 \\
\hline
\end{tabular}


The source of Ricinus lipase material from dormant seeds employed in the experiment was prepared by dehulling and deflating finely powdered castor seeds, while the source Ricinus Lipase from germinated castor seeds was obtained by repeated grinding of five days old germinated seeds to the fine paste. These two experimentally active preparations were used in subsequent experiments to measure the rate of hydrolysis of various substrate and lipase activity

In both the sets of experiments in addition to castor oil (substrate of Ricinus Lipase), linseed, cottonseed, olive and coconut oils were also used as substrate to assess relative substrate specificity of Ricinus acid lipase material obtained from dormant and germinated castor seeds, both.

Results on rate of hydrolysis (percentage fatty acids produced) of various substrate using. Ricinus lipase source from dormant seeds under standard condition are illustrated in table 4.1. It is clear that maximum rate of lipolysis (45\%) under $30 \%$ of incubation period was recorded with castor oil substrate. Olive oil recorded $41.32 \%$ lipolysis followed by coconut oil (40.29\%) while the enzyme source showed lowest lipolysis in case of cottonseed oil .Linseed oil was lipolysed to $34.02 \%$.

Although maximum lipolysis was recorded in the case of castor oil, however, the enzyme material lipolysed other substrate also to a considerable extent indicating its broad substrate specificity for vegetable oils as shown in table 1.

Lipase activity expressed as mew moles of free fatty acids released under substrate condition also recorded similar pattern indicating maximum lipase activity of 22.1 umole per minute. $10 \mathrm{mg}$ enzyme per material when castor oil was used as substrate. Lipase activity with other substrate viz. olive, coconut, linseed and cottonseed oils was found to be in the decreasing order of $20.2,19.7,16.7$ and $15.5 \mu$ mole per minute $10 \mathrm{mg}$ enzyme per material respectively

Table 6 A: Effect of Temperature on the rates of Hydrolysis of Various Glycerides Catalysed by Ricinus lipase Source from Germinated Castor Seeds

\begin{tabular}{|c|c|c|c|c|c|}
\hline \multirow[t]{2}{*}{ Substrate } & \multicolumn{5}{|c|}{ Rate of Hydrolysis (\%)* } \\
\hline & $30^{\circ} \mathrm{C}$ & $35^{\circ} \mathrm{C}$ & $40^{\circ} \mathrm{C}$ & $45^{\circ} \mathrm{C}$ & $50^{\circ} \mathrm{C}$ \\
\hline Castor oil & 3.99 & 4.00 & 4.04 & 4.1 & 4.00 \\
\hline Linseed oil & 2.15 & 2.16 & 2.16 & 2.14 & 2.15 \\
\hline Cottonseed oil & 1,27 & 1.29 & 1.25 & 1.25 & 1.24 \\
\hline Olive oil & 2,98 & 3.04 & 2.95 & 2.86 & 2.58 \\
\hline Coconut oil & 2.49 & 2.50 & 2.56 & 2.46 & 2.41 \\
\hline \multicolumn{6}{|c|}{$\begin{array}{c}\text { Table } 6 \text { B: Activity of Ricinus Lipase Source Obtained from } \\
\text { Germinated Castor Seed as Affected by Temperature }\end{array}$} \\
\hline \multirow[t]{2}{*}{ Substrate } & \multicolumn{5}{|c|}{ Rate of Hydrolysis (\%)* } \\
\hline & $30^{\circ} \mathrm{C}$ & $35^{\circ} \mathrm{C}$ & $40^{\circ} \mathrm{C}$ & $45^{\circ} \mathrm{C}$ & $50^{\circ} \mathrm{C}$ \\
\hline Castor oil & 2.21 & 2.33 & 2.61 & 2.61 & 2.40 \\
\hline Linseed oil & 1.04 & 1.06 & 1.05 & 1.04 & 1.05 \\
\hline Cottonseed oil & 0.61 & 0.62 & 0.61 & 0.60 & 0.61 \\
\hline Olive oil & 1.51 & 1.48 & 1.43 & 1.50 & 1.26 \\
\hline Coconut oil & 1.20 & 1.20 & 1.24 & 1.15 & 1.15 \\
\hline
\end{tabular}


Similar set of experiments under standard condition were also performed using Ricinus lipase source from geminated castor seeds which exhibited drastic release in percentage lipolysis and lipase activity in the case of all the as substrate (Table 1 and 2 ) as compared to experiments performed with Ricinus lipase source from dormant seeds.

It clearly indicated that in dormant castor beans active acid lipase was present, however, it almost disappeared or inactivated in germination seeds. In the case of castor oil lipase activity decreased from 22.1 to $2.33 \mu$ mole per minute $10 \mathrm{mg}$ enzyme per source when germinated seed was used in place of dormant castor seed. Decrease in lipase activity was also observed with all other substrates when lipase source from germinated seeds was used. Similar drastic loss in Ricinus lipase activity in germinated castor seeds has also been observed by Huang and Moreau, Muto and Beevers (1974) and Ory indicating unique behaviour of Ricinus lipase not found in other oilseeds.

\section{Effects of $\mathrm{pH}$}

The \% lipolysis and Ricinus lipase activity as influenced by $\mathrm{pH}$ was also determined using lipase source from dormant and germinated castor seeds (Table $3 A$ \& and $4 A$ \&B).

Rate of hydrolysis and lipase activity using dormant seeds as enzyme Source was recorded at $\mathrm{pH} 4.0,4.8,5.0$ and 5.5 on various substrate at 350 $\mathrm{C}$ as shown in Table $9 \mathrm{~A}$ and $\mathrm{B}$.

When Rienus lipase source from donnant seed was used with all the substrate, it was found that rates of hydrolysis and lipase activity initially increased from $\mathrm{pH} 4$ and reached at its maximum at $\mathrm{pH} 4.8$, thereafter its $\mathrm{pH}$ decreased at 5.5 indicating its $\mathrm{pH}$ at 4.8 .

The $\mathrm{pH}$ optimum of acid lipase of castor bean has been reported to be 4.2 - 4.5 by Ory (1969) while Huang and Moreau (1978) have recorded its

Table 7 A: Effect of reaction time on the Extent of Hydrolysis of Substrates Catalyzed by Ricinus Lipase Source from Dormant Seeds

\begin{tabular}{|c|c|c|c|c|c|}
\hline \multirow[t]{2}{*}{ Substrate } & \multicolumn{5}{|c|}{$\begin{array}{l}\text { Rate of Hydrolysis }(\%)^{\star} \\
\text { Free fatty acid produced }\end{array}$} \\
\hline & $15 \mathrm{~min}$. & $30 \mathrm{~min}$. & $60 \mathrm{~min}$. & $90 \mathrm{~min}$. & $120 \mathrm{~min}$. \\
\hline Castor oil & 32.19 & 45.00 & 50.50 & 55.26 & 72.26 \\
\hline Linseed oil & 72.26 & 21.91 & 34.02 & 43.35 & 45.19 \\
\hline Cottonseed oil & 46.22 & 19.61 & 3.1 .65 & 40.02 & 49.25 \\
\hline Olive oil & 52.25 & 29.23 & 41.32 & 49.92 & 59.25 \\
\hline Coconut oil & 60.25 & 26.52 & 40.29 & 42.12 & 44,26 \\
\hline
\end{tabular}

Table 7 B: Effect of reaction time on the Activity of Ricinus Liase Source Obtained from Dormant Castor Seeds using Various Substrates

\begin{tabular}{lccccc}
\hline Substrate & \multicolumn{5}{c}{ Rate of Hydrolysis (\%) } \\
& $\begin{array}{l}\text { ( } \boldsymbol{\mu} \text { mole F.A. released minute } \\
\text { 15 } \mathbf{~ m i n . ~}\end{array}$ & $\mathbf{3 0}$ min. & $\mathbf{6 0}$ min. & $\mathbf{9 0}$ min. & $\mathbf{1 2 0}$ min. \\
& & & & & \\
\hline Castor oil & 15.8 & 22.1 & 24.8 & 27.1 & 35.4 \\
Linseed oil & 10.7 & 16,7 & 21.2 & 22,1 & 22.6 \\
Cottonseed oil & 9,60 & 15.5 & 19.5 & 24.1 & 25.8 \\
Olive oil & 14.2 & 20.2 & 24.4 & 28.9 & 29.4 \\
Coconut oil & 12.0 & 19.7 & 20.5 & 20.6 & 21.0 \\
\hline
\end{tabular}


$\mathrm{pH}$ to be 5.0 which is almost in agreement with the results recorded by the author

Similar sets of experiment conducted with Ricjpps lipas source from germinated castor beans did pot show any impact of alteration in $\mathrm{pH}$ values on the rates of lipolysis and lipase activity various substrate and recorded almost negligible value (table 4.4 A and B) Huang and Moreau (1978) have also recorded negligible activity in 6 day old germinated seeds of castor at ph 5.0.

\section{Effect of Temperature}

Effect of varying temperature $(30,35$, 40,45 and $50^{\circ} \mathrm{C}$ ) on the lipase activity and rates of hydrolysis of different substrate using lipase enzyme source from dormant and germinated castor from dormant and castor seeds was also recorded, other conditions of the reaction were same as in standard condition. The results are depicted in Table $5 \mathrm{~A} \& \mathrm{~B}$ and $6 \mathrm{~A} \& \mathrm{~B}$.
Results showed that rates of hydrolysis and lipase activity increased up to $40^{\circ} \mathrm{Celsius}$ and then showed declining trend at $45{ }^{\circ} \mathrm{C}$ recording lowest value at $50^{\circ} \mathrm{C}$ in almost all the substrates in the case of Ricinus lipase source from dormant seeds as shown in Table 5 A \& $B$.

Similar Trend Indicating increase in lipase activity at $40 \mathrm{deg}$ Celsius compared to $35 \mathrm{deg}$ Celsius in the case of Ricinus lipase activity on castor oil as substrate has also been recorded by Ory et al. (1962).

When germinated castor seeds were used as lipase source, incubation at the various temperature did not bring about any noticeable change on the rates of hydrolysis and lipase activity irrespective of any substrate used as shown in Table $6 \mathrm{~A}$ and $\mathrm{B}$. The data remained almost static as those observed in the case of experiments conducted under standard condition using germinated castor

Table 8 A: Effect of Reaction Time on the Rate of Hydrolysis of Various Substrates Catalyzed by Ricinus Lipase Source from GCS

\begin{tabular}{|c|c|c|c|c|c|}
\hline \multirow[t]{2}{*}{ Substrate } & \multicolumn{5}{|c|}{$\begin{array}{l}\text { Rate of Hydrolysis }(\%)^{*} \\
\text { Free fatty acid produced }\end{array}$} \\
\hline & $15 \mathrm{~min}$. & $30 \mathrm{~min}$. & $60 \mathrm{~min}$. & $90 \mathrm{~min}$. & $120 \mathrm{~min}$. \\
\hline Castor oil & 0.15 & 4.00 & 4.00 & 4.03 & 4.03 \\
\hline Linseed oil & 0.52 & 2.16 & 2.19 & 2.22 & 2.19 \\
\hline Cottonseed oil & 0.31 & 1.29 & 1.29 & 1.28 & 1.26 \\
\hline Olive oil & 0.26 & 3.04 & 3.03 & 3.02 & 3.03 \\
\hline Coconut oil & 0.01 & 2.50 & 2.55 & 2.55 & 2.58 \\
\hline \multicolumn{6}{|c|}{$\begin{array}{c}\text { Table } 8 \text { B: Effect of Reaction Tune on the Activity of Ricinus Lipase } \\
\text { Source Obtained from GCS using Various Substrates }\end{array}$} \\
\hline \multirow[t]{3}{*}{ Substrate } & \multicolumn{5}{|c|}{ Ricinus lipase activity ${ }^{\star}$} \\
\hline & ( $\mu$ mole & A. releas & d minute & Omg lipas & source $\left.{ }^{-1}\right)$ \\
\hline & $15 \mathrm{~min}$. & $30 \mathrm{~min}$. & $60 \mathrm{~min}$. & $90 \mathrm{~min}$. & $120 \mathrm{~min}$. \\
\hline Castor oil & 0.08 & 2.33 & 2.33 & 2.34 & 2.34 \\
\hline Linseed oil & 0.087 & 1.06 & 1.07 & 1.06 & 1.06 \\
\hline Cottonseed oil & 0.062 & 0.62 & 0.63 & 0.63 & 0.61 \\
\hline Olive oil & 0.090 & 1.48 & 1.45 & 1.44 & 1.45 \\
\hline Coconut oil & 0.089 & 1.20 & 1.22 & 1.20 & 1.22 \\
\hline
\end{tabular}


seeds as lipase source. It clearly indicated loss of acid lipase activity $n$ germinated seeds as compared to dormant castor seeds as reported by others.

\section{Effects of Reaction Time}

Rates of hydrolysis and lipase activity of enzyme material from dormant seeds was measured using various substrates at different reaction time viz $15,30,60,90$ and 120 minutes. The rates of showed linear increase with the increase in reaction time when castor oil was used as substrate. Similar trend was observed in linseed, cottonseed olive and coconut oil, however, magnitude of increase in fatty acids released was different with each substrate as depicted in Table 7A. Maximum value of lipase activity in during 120 minute of reaction hue was $35.4,29.4$, $25.8,22.6$. and $21.0 \mu$.

Table 9 A: Effect of Ricinus Lipase Concentration (obtained from DCS) on the Extent of Hydrolysis of substrate

\begin{tabular}{lllll}
\hline Substrate & \multicolumn{5}{c}{ Rate of Hydrolysis (\%)* } \\
& $\begin{array}{l}\text { Ricinus lipase concentration } \\
\mathbf{0 . 0 5 g}\end{array}$ & $\mathbf{0 . 1 0 g}$ & $\mathbf{0 . 1 5 g}$ & $\mathbf{0 . 2 0 g}$ \\
& & & & \\
\hline Castor oil & 42.00 & 45.00 & 47.92 & 50.12 \\
Linseed oil & 30.06 & 34.02 & 36.16 & 38.12 \\
Cottonseed oil & 29.15 & 31.65 & 32.06 & 34.12 \\
Olive oil & 39.13 & 41.32 & 43.61 & 44.00 \\
Coconut oil & 37.12 & 40.29 & 42.10 & 44.36 \\
\hline
\end{tabular}

Table 10 A: Effect of Ricinus Lipase Concentration (from RCS) on the Rate of hydrolysis of various substrate

\begin{tabular}{lcccc}
\hline Substrate & \multicolumn{5}{c}{ Rate of Hydrolysis (\%)* } \\
& \multicolumn{1}{c}{ Ricinus lipase concentration } \\
& $\mathbf{1 . 6 g}$ & $\mathbf{2 . 1 g}$ & $\mathbf{2 . 6} \mathbf{~ g}$ & $\mathbf{3 . 1 9}$ \\
& & & & \\
\hline Castor oil & 4.00 & 4.00 & 5.06 & 5.10 \\
Linseed oil & 2.11 & 2.16 & 2.14 & 2.14 \\
Cottonseed oil & 1.28 & 1.29 & 1.26 & 1.27 \\
Olive oil & 2.58 & 3.04 & 3.05 & 3.09 \\
Coconut oil & 2.47 & 2.50 & 2.50 & 2.50 \\
& & & & \\
\hline
\end{tabular}

Moles per minute 10mg enzyme per source in the case of castor oil, olive oil, cottonseed oil, linseed oil and coconut oil substrates respectively (Table 7). Similar type of linear increase in lipase activity with the increase in reaction time also has been reported by Sabders and Pattee (1975) in the case of peanut lipase using tributyrin as substrate and by Longnecker and Haey in the case of Ricunus lipase dormant castor seeds using olive oil as substrate . ${ }^{\circ} \mathrm{W}$ et al (1960) have also obtained a plot of glyceride concentration versus reaction time in straight line in the case of hydrolysis of endogenous castor oil by crude Ricinus lipase donnant seed.

Rate of hydrolysis and lipase activity measured using germinated castor seeds as lipase source with various substrate did not show alterations

Table 9 B: Effect of Enzyme Concentration on source obtained from DCS using various substrate

\begin{tabular}{lcccc}
\hline & \multicolumn{4}{c}{ Ricinus lipase activity* } \\
Substrate & \multicolumn{4}{c}{$\begin{array}{c}\text { 10mg lipase source) } \\
\text { Enzyme concentration }\end{array}$} \\
& $\mathbf{0 . 0 5 g}$ & $\mathbf{0 . 1 0 g}$ & $\mathbf{0 . 1 5 g}$ & $\mathbf{0 . 2 0 g}$ \\
& & & & \\
\hline Castor oil & 20.6 & 22.1 & 23.5 & 24.6 \\
Linseed oil & 14.7 & 16.7 & 17.7 & 18.7 \\
Cottonseed oil & 14.2 & 15.5 & 15.7 & 16.7 \\
Olive oil & 19.1 & 20.2 & 21.3 & 21.5 \\
Coconut oil & 18.1 & 19.7 & 20.5 & 21.6 \\
& & & & \\
\hline
\end{tabular}

Table 10 B: Ricinus Lipase Activity as affected by Concentration of Lipase Enzyme Source from GCS

\begin{tabular}{lcccc}
\hline Substrate & \multicolumn{4}{c}{ Ricinus lipase activity* } \\
& \multicolumn{4}{c}{$\begin{array}{c}\text { 10mg lipase source } \\
\text { ( } \mathbf{~ m o l e ~ F . A . ~ r e l e a s e d ~ m i n u t e ~}\end{array}$} \\
& $\mathbf{1 . 6 g}$ & $\mathbf{2 . 1 g}$ & $\mathbf{2 . 6 ~ g}$ & $\mathbf{3 . 1 9}$ \\
& & & & \\
\hline Castor oil & 2.31 & 2.33 & 2.37 & 2.39 \\
Linseed oil & 1.07 & 1.05 & 1.06 & 1.06 \\
Cottonseed oil & 0.62 & 0.62 & 0.61 & 0 \\
Olive oil & 1.41 & 1.48 & 1.46 & 0.91 \\
Coconut oil & 1.21 & 1.20 & 1.21 & 1.21 \\
\hline
\end{tabular}


with the in reaction period which may be attributed to the loss of lipase activity in germinated Ricinus beans (Table $8 \mathrm{~A}$ and $\mathrm{B}$ ).

\section{Effects of enzyme concentration}

Effect of concentration of enzyme on the rate of hydrolysis of castor oil and other substrate using source from dormant seed as shown in table 9 A. It clearly indicated linear increase in the percent hydrolysis and lipase activity with the increase in enzyme concentration Maximum rate of hydrolysis was recorded to be $50.12 \%$ in the case of castor oil as substrate using $0.2 \mathrm{~g}$ enzyme material from dormant castor seeds at $\mathrm{pH} 4.8$ during $30 \mathrm{~min}$. at $35^{\circ} \mathrm{C}$. Maximum rate of hydrolysis of coconut oil

Table 11 A: Effect of Substrate Concentration on the Rate of Hydrolysis of various Glycerides using Ricinus lipase from DCS

\begin{tabular}{lcccc}
\hline Substrate & \multicolumn{5}{c}{ Rate of Hydrolysis (\%)* } \\
& $\mathbf{0 . 0 5 g}$ & $\mathbf{0 . 1 0 g}$ & $\mathbf{0 . 1 5 g}$ & $\mathbf{0 . 2 0 g}$ \\
& & & & \\
\hline Castor oil & 44.28 & 45.00 & 48.13 & 46.70 \\
Linseed oil & 33.72 & 34.02 & 37.19 & 39.25 \\
Cottonseed oil & 30.40 & 31.65 & 33.00 & 35.12 \\
Olive oil & 40,56 & 41.32 & 43.65 & 42.12 \\
Coconut oil & 38.71 & 40.29 & 42.90 & 39.65 \\
\hline
\end{tabular}

Table 11 B: Effect of Substrate Concentration on the Activity of Ricinus lipase source obtained from DCS using various substrates

\begin{tabular}{|c|c|c|c|c|}
\hline \multirow[t]{2}{*}{ Substrate } & \multicolumn{4}{|c|}{$\begin{array}{c}\text { Ricinus lipase activity } \\
\text { ( } \mu \text { mole F.A. released minute }{ }^{-1} \\
\text { 10mg lipase source }{ }^{-1} \text { ) } \\
\text { Substrate concentration }\end{array}$} \\
\hline & $0.5 \mathrm{~g}$ & $1.0 \mathrm{~g}$ & $1.5 \mathrm{~g}$ & $2.0 \mathrm{~g}$ \\
\hline Castor oil & 21.6 & 22.1 & 23.6 & 22.9 \\
\hline Linseed oil & 16.5 & 16.7 & 18.2 & 19.2 \\
\hline Cottonseed oil & 14.8 & 15.5 & 16.1 & 17.1 \\
\hline Olive oil & 19.8 & 20.2 & 21.3 & 20.5 \\
\hline Coconut oil & 18.9 & 19.7 & 20.9 & 19.3 \\
\hline
\end{tabular}

* Mean of three measurements, FA fatty acids and olive oil using $.2 \mathrm{~g}$ of concentration Of enzyme material from dormant seed under same condition was found to be $44.36 \%$ and $44.00 \%$. Lowest rate of hydrolysis (34.12\%) was recorded when cottonseed oil was used as substrate as shown in Table $9 \mathrm{~A}$. It clearly indicated linear increase in the percent hydrolysis and lipase activity with the increase in the percent hydrolysis and lipase activity with the increase in enzyme concentration .Maximum rates of hydrolysis was recorded to be $50.12 \%$ in the case of castor oil as substrate using. enzyme material from dormant castor seeds at $\mathrm{pH} 4.8$ during $30 \mathrm{~mm}$. at 35 deg Celsius . Maximum rate of hydrolysis of coconut oil and olive oil using $.2 \mathrm{~g}$ of concentration of enzyme material from dormant seed under same condition

Table 12 A: Effect of Substrate Concentration on the Rate of Hydrolysis of Various

Substrates Catalyzed by Ricinus Lipases Source from OCS

\begin{tabular}{lcccc}
\hline Substrate & \multicolumn{4}{c}{ Rate of Hydrolysis (\%)* } \\
& Substrate concentration \\
& $\mathbf{0 . 0 5 g}$ & $\mathbf{0 . 1 0 g}$ & $\mathbf{0 . 1 5 g}$ & $\mathbf{0 . 2 0 g}$ \\
\hline Castor oil & 4.01 & 4.00 & 4.00 & 3.96 \\
Linseed oil & 2.14 & 2.16 & 2.10 & 2.13 \\
Cottonseed oil & 1.26 & 1.29 & 1.29 & 1.26 \\
Olive oil & 3.05 & 3.04 & 2.99 & 2.96 \\
Coconut oil & 2.51 & 4.00 & 2.42 & 2.37 \\
\hline
\end{tabular}

Table 12 B: Effect of Substrate Concentration on the Activity of Ricinus lipase source obtained from DCS using various substrates

\begin{tabular}{lcccc}
\hline Substrate & \multicolumn{4}{c}{ Ricinus lipase activity* } \\
& \multicolumn{4}{c}{$\begin{array}{c}\text { 10mg lipase source-1) } \\
\text { Substrate concentration }\end{array}$} \\
& $\mathbf{0 . 5 g}$ & $\mathbf{1 . 0 g}$ & $\mathbf{1 . 5 g}$ & $\mathbf{2 . 0 g}$ \\
\hline Castor oil & 2.28 & 2.33 & 2.37 & 2.37 \\
Linseed oil & 1.0 & 1.06 & 1.00 & 1.00 \\
Cottonseed oil & 0.61 & 0.62 & 0.62 & $(.61$ \\
Olive oil & 1.48 & 1.48 & 1.42 & 1.36 \\
Coconut oil & 1.24 & 1.20 & 1.20 & 1.15 \\
\hline
\end{tabular}


Table 13: Effect of Inorganic Salts on the rate of hydrolysis on various Substrates catalyzed by Ricinus Lipase Source from DCS

\begin{tabular}{|c|c|c|c|c|c|}
\hline \multirow[t]{2}{*}{ Substrate } & \multicolumn{5}{|c|}{ Rate of Hydrolysis (\%)* } \\
\hline & Castor oil & Linseed oil & Cotton Seed Oil & Olive oil & Coconut oil \\
\hline Nil (Control) & 45.00 & 34.02 & 31.65 & 41.32 & 40.29 \\
\hline Lead acetate & 20.12 & 27.22 & 31.20 & 25.12 & 22.29 \\
\hline Manganese acetate & 22.25 & 20.25 & 21.92 & 19.15 & 21.21 \\
\hline Calcium acetate & 25.00 & 20.12 & 23.29 & 24.29 & 24.01 \\
\hline Lead chloride & 15.29 & 12.21 & 13.12 & 14.29 & 16.29 \\
\hline Cobalt acetate & 15.22 & 14.19 & 20.25 & 13.25 & 14.52 \\
\hline Chromium acetate & 14.32 & 12.25 & 14.00 & 14.25 & 13.56 \\
\hline Chromium chloride & 13.12 & 15.51 & 16.29 & 14.25 & 13.25 \\
\hline Calcium chloride & 10.22 & 12.25 & 12.12 & 9.25 & 11.92 \\
\hline Cobalt Chloride & 10.2 & 10.00 & 15.55 & 11.52 & 9.25 \\
\hline
\end{tabular}

* Mean of two replication, DCS=Dormant castor seed

was found to be $44.36 \%$ and $44.00 \%$. Lowest rate of hydrolysis (34.12\%) was recorded when cottonseed oil was used as substrate as shown in Table 9 A.

Activity of lipase from dormant seed expressed as $\mu$ molar concentration of ay released also revealed similar pattern of linear increase with the increase in enzyme concentration with all the substrate indicating maximum lipase activity of 24.6 , $18.7,16.7,21.5$ and $21.6 \mathrm{t}$ mole per minute $10 \mathrm{mg}$ lipase per source when castor, linseed, cottonseed, olive and coconut oils, respectively, were used as substrate (Table 9 B)

Data on the effect of enzyme concentration on the rate of hydrolysis of various substrate clearly indicated broad specificity of Ricinus lipase from dormant seed .Data obtained by the author is in agreement with those reported by Wetter and Lin and Huang on lipases from rape and mustard and Hassanien and Mukharjee on lipases from rape, mustard and lupine seedlings. Findings of Ory et al (1962) on the effect of enzyme concentration of acid lipase from castor bean on the rate of hydrolysis of castor oil is almost in accordance with the results obtained by the author.

Effect of enzyme concentration on the activity of Ricinus lipase source from genninated castor seeds were also recorded as shown in Table
$10 \mathrm{~A}$ and B. Rates of Hydrolysis of various oils used as substrate remained almost unaffected with the increase in enzyme concentration. Moreover rates of hydrolysis of different vegetable oils were very poor as compared to the rates of hydrolysis recorded with lipase from dormant seed under similar reaction conditions indicating loss of lipase activity in germinated castor beans. Such type of behaviour in germinated castor seeds has also been reported by Huang and Moreau. Same trend was observed when lipase activity from germinated seed was measured in a mew molar concentration of free fatty acid released

\section{Effect of substrate concentration}

Effect of increasing the substrate concentration on the rates of hydrolysis of various vegetable oils (substrate) at $35^{\circ}$ Celsius using Ricinus Lipase source from dormant seed showed two different pattern in Table 11 A \& B

Data on lipase activity expressed as mew moles of free fatty acid released from triglycerides (substrates) as influenced by increasing the concentration of respective substrates in illustrated in Table 11.

Increasing the concentration of castor oil as substrate from $0.5 \mathrm{~g}$ to $1.5 \mathrm{~g}$ increased lipase activity to its maximum,there after it decreased. Same 
pattern was recorded when olive oil and coconut oil were used as substrates. Cottonseed and olive oils recorded linear increase in lipase activity with the increasing concentration of respective substrates (Table $11 \mathrm{~B}$ )

The Lipase activity and rates of hydrolysis of various substrate as affected substrate concentration was also determined using lipase source from $\mathrm{d}$ day old germinated caster seeds (Table $12 \mathrm{~A}$ \& B), however, it did not produce any meaningful results

\section{Effect of Inorganic Salts on the rate of Hydrolysis on Different Substrates}

Effect of certain inorganic salts which included acetates and chlorides of lead calcium cobalt, chromium and acetate of manganese ( $\mu \mathrm{g}$ each) on the Ricinus lipase catalyzed hydrolysis of various substrates using lipase source from dormant castor seeds was also studied to examine the inhibitory or circulatory action of added salts on catalytic activity of lipase. Results on the rates of hydrolysis of each substrate as compared to control are shown in table 1.

Each added salt inhibited lipase catalysed hydrolysis of substrates but the magnitude of inhibitory action varied depending on inorganic salts and substrate used. Least inhibitory effect was noticed in acetates of lead, manganese and calcium in almost all substrates while moderate inhibitory action was recorded in the case of all substrates when lead chloride, cobalt acetate, chromium acetate and chromium chloride were added to reaction mixture. Maximum inhibition was exhibited by calcium and cobalt chloride in the case of all substrates. Similar inhibitory action of inorganic salts on Ricinus lipase activity have also been observed by Longnecker and Haleyand Ory et al. the results of which are in agreement with the findings recorded by author.

\section{REFERENCES}

1. Stumpf.P.K. Lipid metabolism In : plant Biochemistry (Bonner, J, and vemer, J.F., Editors), Academic Press, New York, 1976 ,427.

2. Beevers.H. Glyoxysomes of castor bean endosperm and their nation to gluconeogenesis Ann. N.Y. Acad. Sci. 1969,168,323,

3. Beevers.H Organelles from castor bean seedlings: Biochemical roles in gluconeogenesis and phospholipid biosynthesis In: Recent Advances in the Chemistry and Biochemistry of Plant Lipids (Galliard, T. and Mercer, E.I., Editors), Academic Press New York, ,1975,287

4. Bamann.E. and Ullrnann.E. Lipases In: Encyclopedia of plant physiollogy. (Ruhland, W.B.,Editor), Springer Berlin Heidelberg,1957 7, 109

5. Butt.V.S. and Beevers.H. The plant lipids; In: Plant Physiology (F.C. Steward, Editor) Academic Press, New York, ,1966,4,465

6. Matite.P. The lytic compartments of plant cells IN : cell Biology Monographs. (Alfert et et al., Editors), Springer, New York, 1975103.

7. Ory.R.L.,Angelo.J.St.and Altschul. A.M.
Castor bean lipase action on its endogenous substrate, J. lipid Research, 1960, 1,208,

8. Ory.R.L., Yatsu.L.Y.and Kircher,.H.W. Association of lipase activity with the spherosoines of Ricinus commun Es, Arch. Biochem. (1968), 5,

9. Ory.R.L. Angelo J.st and Altschul.A.M. The acid lipase of castor bean - properties and substrate specificity, J. Lipid Research 8,99, Ory.R Acid lipase of castor beans, Lipids, 1969, 4,177,

10. Huang. A.H.C. and Moreau.R.A. Lipases in the storage tissues of peanut and other oil seeds during germination Planta, 1978, 141,(i)111,

11. Longenckar.H.E. and Haley.D.E. Nature of Ricinus Lipase and its nature. J. Amer. Chem. Soc., 1935, 57, 2019,

12. Kulkarni L.G. and Ramanu musthy.G.V. Castor, ICAR, NEW Delhi 1959,46,

13. Nagraj.G. Biochemical Qulaity of oilseed. J. Oil Seed Research, 1990 7, 47,

14. Ghosh Oil content of castor seeds as affected by climate and other conditions. Agri. J. India, 1924, 19, 81, 
15. Bolley.D.S. Composition of castor oil by optical activity. J. Amer. Oil Chemical Soc., 1953, 396,

16. Lakshminarayan.G., Subha Rao R., Sita Ram Shashtri, Y. and Kale V. High pressure spiliting of castor oil, J. Amer. Oil Chemical. Soc. 1984 61(7) 1204,

17. Gardener.H.K., D a quinE.L. Koltum,S.P.Macourtney Vix H.I.E. and Gastrock.E.A. Detoxification and deallergination of castor beans, J. Amer. Oil Chem. Soc. $1960 \quad 37,142$

18. Rao. K.V.S.A., Paulose, M.M. and Lakshminarayan In situ lipolysis of castor oil in homogenous castor seeds, Biotechnology Letters,1990, 12, 377

19. Longencker.H.E. and Haley.D.E. further studies on nature of Ricinus lipase and its action, J. Am. Chem. Soc. 1937, 59, 2156,

20. Hassanien.F.R. and Mukherjee. K.D. isolation of lipase from germinating oil seeds for biotechnological processes J. Amer. Oil Chem. Soc. 1986,63(67) 893,

21. Theimer.R.R. and Inge.R. Development and intracellular localization of lipase activity in rapeseed (Brassica napus L.) cotyledons, Planta, 1978, 139, 244, 